\title{
Active immunization against somatostatin increases milk yield in goats
}

\author{
G. J. Garssen ${ }^{1}$, A. M. A. W. Welling ${ }^{1}$ and G. S. G. Spencer ${ }^{2}$ ( ${ }^{1}$ Research Institute \\ for Animal Production 'Schoonoord', P.O. Box 501, 3700 AM Zeist, Netherlands; \\ ${ }^{2}$ Biovet Unit, Ciba-Geigy, Centre de Recherches Agricoles, CH-1566 Saint-Aubin \\ FR, Switzerland)
}

Received 25 September 1986; accepted 24 November 1986

\begin{abstract}
The effect of immunoneutralization of somatostatin on milk production of goats was studied. Goats were immunized with a conjugate of somatostatin and human $\alpha$-globulin halfway their pregnancy and again post-partum. The lactation curves were different over the first 10 weeks of lactation with the goats immunized against somatostatin producing $9 \%$ more milk. The milk concentrations of fat, protein and lactose were the same for both treated and control goats.

These results suggest that active immunization against somatostatin may enhance milk production in goats in early lactation.

Key words: somatostatin, immunization, milk production, birth weight, goat.
\end{abstract}

Introduction. A number of hormones interact to regulate milk production, and among them growth hormone plays an important role, notably in the maintenance of the lactation. Increments of the circulating growth hormone concentration thus may stimulate milk production. It has already been shown that administration of exogenous growth hormone enhances milk yield in lactating cows, sheep and goats (Bines \& Hart, 1982; Bauman \& McCutcheon, 1986). On the other hand, immunoneutralization of somatostatin, a peptide which inhibits the secretion of a number of hormones, such as growth hormone, might be another approach. Some indications for an increased stimulation of growth hormone release have already been found in growing lambs (Spencer et al., 1983). The present experiment investigates the effect of active immunization against somatostatin in pregnant goats on prenatal growth and milk production.

Material and methods. Six Dutch white goats were immunized against a conjugate of somatostatin and human serum $\alpha$-globulin. Six goats were immunized against the globulin as controls. All goats were to enter their second lactation. The primary immunization was with Freund's Complete Adjuvant plus an injection of Bordetella pertussis (i.m.) at the tenth week of gestation; a booster immunization was given 15 weeks later, i.e., in the fourth week of lactation. The groups had been balanced as regards live weight and previous lactation records. During gestation the goats were group-housed and they were individually penned after delivery. Their intake of hay and concentrates (offered ad libitum) was determined. The goats 
were machine-milked twice a day. Each week they were weighed, and both a morning and an evening sample of milk from each goat was analysed for composition. Jugular vein blood samples were taken every three weeks and analysed for metabolites (free fatty acids, glucose, $\beta$-hydroxybutyric acid) and somatostatin antibody titres.

Upon delivery the kids were weighed and removed from the goats after taking colostrum.

Results and discussion. After the primary and booster injection all anti-somatostatin-treated goats showed antibody titres against somatostatin as distinct from the control animals. There was an indication of an increased birth weight in the offspring of the anti-somatostatin-treated goats (Table 1), but in an analysis of variance the differences were not statistically significant.

During the early part of lactation (10 weeks) the goats immunized against somatostatin produced more milk than the control goats, weekly yields being significantly different $(P<0.05)$ during the first and third week. The total production over the first 10 weeks per goat was $288.9 \pm 11.2$ and $265.1 \pm 15.3 \mathrm{~kg}$ (mean \pm s.e.m.) for the treated and control goats respectively. The concentrations of fat, protein and lactose, however, did not differ. Only during the third week of lactation there was a significant difference in dietary energy intake between the two groups, the treated group having a higher appetite. Throughout the period of the study there was no difference in body weight of the two groups. The treated goats had a consistent $2 \%$ greater advantage in milk energy as a percentage of gross food energy throughout the period of study. The higher energy output in the milk presumably did not take place at the expense of tissue energy because no differences between the groups were found in the blood concentrations of free fatty acids, glucose and $\beta$-hydroxybutyric acid. We suggest that the increased feed intake is used for an enhanced milk production rather than for tissue deposits.

The effects of immunoneutralization of somatostatin in goats and sheep could be of twofold benefit. First, larger birth weights could give rise to a faster growth postnatally (McKeown et al., 1976). In this respect, more studies are required. Second, since early postnatal nutrition is also a major determinant of the subsequent growth of an animal, an increased milk production during the postnatal period may be of

Table 1. Birth weights (g, mean \pm s.e.m.) of kids from goats immunized against somatostatin (treated) and control goats immunized against globulin (control).

\begin{tabular}{lcccc}
\hline Treatment & Females & (n) & Males & (n) \\
& & & & \\
Treated & $3451 \pm 160$ & $(6)$ & $3949 \pm 163$ & $(7)$ \\
Control $^{*}$ & $3128 \pm 344$ & $(5)$ & $3432 \pm 121$ & $(6)$
\end{tabular}

* During pregnancy, one goat from the control group (carrying 4 kids) died from acetonaemia. 
importance particularly when nutrient supply may be limited such as with multiple births in sheep. The results of the present study suggest that immunization against somatostatin increases milk yield in the postnatal period of the goat.

\section{References}

Bauman, D. E. \& S. N. McCutcheon, 1986. The effects of growth hormone and prolactin on metabolism. In: L. P. Milligan, W. L. Grovum \& A. Dobson (Eds.), Control of digestion and metabolism in ruminants, p. 436-454. Prentice-Hall, Englewood Cliffs, N.J.

Bines, J. A. \& I. C. Hart, 1982. Metabolic limits to milk production, especially roles of growth hormone and insulin. Journal of Dairy Science 65: 1375-1389.

McKeown, T., T. Marshall, \& R. G. Record, 1976. Influences on fetal growth. Journal of Reproduction and Fertility 47: 167-181.

Spencer, G. S. G., G. J. Garssen \& I. C. Hart, 1983. A novel approach to growth promotion using autoimmunisation against somatostatin. I. Effects on growth and hormone levels in lambs. Livestock Production Science 10: 25-37.

This synopsis is based on Report B-288, Research Institute for Animal Production 'Schoonoord', Zeist, Netherlands, 1986. 20 pp., 5 figs., 1 table, 20 refs. English. Available as paper copy (order R067P, free) or microfiche (order R067M, $f 12.50$ including postage) at: NARD, clo Pudoc, P.O. Box 4, 6700 AA Wageningen, Netherlands (telex 45015 blhwg). 